ROCZNIKI FILOZOFICZNE

Tom LXVII, numer $2-2019$

DOI: http://dx.doi.org/10.18290/rf.2019.67.2-9

\title{
JOSÉ ORTEGA Y GASSET
}

\section{NIE BYĆ CZŁOWIEKIEM PARTYJNYM*}

\section{KIM PAN JEST?}

Sytuacją, która najbardziej oburza niektórych ludzi, jest ta, gdy ktoś nie przyłącza się ani do ich partii, ani do partii przeciwników, lecz przyjmuje

JoSÉ ORTEGA Y GASSET (1883-1955) — hiszpański filozof, eseista, społecznik. Uczeń Georga Simmla, Hermanna Cohena i Paula Natorpa. Początkowo pozostawał pod wpływem neokantowskiego idealizmu i fenomenologii Husserla. W późniejszym okresie ufundował własne stanowisko filozoficzne znane jako racjo-witalizm lub filozofia rozumu witalnego. Pragnął przezwyciężyć dychotomie idealizm-realizm oraz racjonalizm-witalizm. Uznawał, że źródłową rzeczywistością jest życie konkretnego człowieka, który musi mierzyć się ze swoimi okolicznościami. W tym celu potrzebny jest rozum, który pozwala orientować się i nadawać sens otaczającemu światu. Rozum staje się praktyczną funkcją człowieka, rozumem witalnym, zakorzenionym w życiu i z życia wyrastającym. Ortega kładł szczególny nacisk na autentyczność ludzkiej egzystencji, która polega na konieczności realizacji konkretnego, indywidualnego powołania, zwanego także przeznaczeniem. Nasze powołanie nakazuje nam być tym, kim jesteśmy, tym, kim być musimy. Wskazuje to na tkwiąca w życiu dialektykę konieczności i wolności oraz na jego przyszłościowy charakter. Życie jest projektem, lecz nie projektem dowolnym i przez nas wymyślonym, lecz nam niejako narzuconym. Jesteśmy jednak wolni w decyzji o akceptacji bądź też odrzuceniu naszego powołania. Z tym, że decydując się na jego odrzucenie skazujemy się na życie w kłamstwie, na nieautentyczność naszego życia. Ortega podkreślał też ścisły związek człowieka i świata, który go bezpośrednio otacza tj. ,ja” i jego okoliczności. Nasze życie nie ogranicza się zatem ani do czystej subiektywności, ani też obiektywności, lecz zawiera się w ich dynamicznej, wydarzającej się koegzystencji. Najważniejsze prace Ortegi to: Meditaciones del Quijote (1914), El tema de nuestro tiempo (1923), La rebelión de las masas (1930) czy też wydana pośmiertnie La idea de principio en Leibniz y la evolución de la teoría deductiva (napisana w 1947 r.).

* Oryginał: José ORTEGA Y GASSET, „No ser hombre de partido”, w: IDEM, Obras completas, t. IV (Madrid: Fundación José Ortega y Gasset/Taurus, 2005), 306-313. Zgodę na przekład i jego publikację wyrazili spadkobiercy Ortegi, reprezentowani przez Andreasa Ortegę Kleina.

Przekład tekstu jest elementem pracy badawczej realizowanej w ramach następujących projektów: 1. Między ideologiq a filozofia. Recepcja G. W. F. Hegla w Hiszpanii, finansowanego ze środków przyznanych przez Narodowe Centrum Nauki, nr rej. projektu: 2013/ 11/D/HS1/04414, oraz Idea polityki realizacji w ujęciu José Ortegi y Gasseta, finansowanego ze środków Narodowego Centrum Nauki, nr rej. Projektu: 2015/19/B/HS1/01010. 
postawę poza te partie wykraczającą i niesprowadzalną do żadnej z nich. Oznacza to usytuowania się au-dessus de la mêlée i jest dla tych ludzi nie do zniesienia. Ja natomiast uważam, że wymóg, aby wszyscy byli partyjni, stanowi jedną z najgorszych, najbardziej rujnujących i absurdalnych chorób, jakie toczą nasze czasy. Na szczęście staje się on coraz bardziej archaiczny, przebrzmiały i zmienia się w pustą gestykulację. Tym samym wzrasta liczba ludzi, którzy uważają go nie tylko za idiotyczny, ale i za głęboko niemoralny, trzymając się żarliwie innej zasady: „Nie być człowiekiem partyjnym”.

Nie sposób zaprzeczyć jednak, że imperatyw partyjności miał w ciagu ostatnich dwudziestu lat tak duży wpływ, że określał ów okres aż po dzień dzisiejszy. Był więc i jest ważnym symptomem czasu, zasługującym na szczegółową analizę. Ta, która zostanie tutaj przeprowadzona, ograniczy się do ukazania tylko niektórych jego aspektów.

Przed zbadaniem jakiejś doktryny wypada jasno określić, kto ją podtrzymuje i rozpowszechnia. To zaoszczędza nam zwykle sporo pracy. Tak też jest i w tym przypadku. Ci, którzy występują przeciwko osobom sytuującym się, ich zdaniem, au-dessus de la mêlée, są zawsze ludźmi tego samego pokroju. Nie przemyśleli oni źródłowo idei, wokół której się zjednoczyli, a która uformowała ich mêlée. W ogóle nigdy niczego nie przemyśleli sami, lecz znaleźli gotową już partię i wsiedli do niej tak, jak wsiada się do autobusu. Uczynili to, aby do celu nie musieć docierać na własnych nogach. Wsiedli do niej, aby dać sobie odpocząć. Istnieją bowiem ludzie, którzy są sobą zmęczeni od samego urodzenia. Proszę nie sądzić, że jest to jakiś nieistotny detal. Człowiek od początku mający wstręt do siebie jest kategorialnym typem ludzkości. Ten wstręt staje się samym centrum jego bytu, a wszystko, co robi, robi po to, aby od siebie uciec. Do tego zmusza go zmęczenie.

Spyta ktoś: Skąd bierze się ów dziwny wstręt i ucieczka od siebie? Pytanie to jest zbyt ważne, aby móc na nie odpowiedzieć w krótkim artykule. Odpowiedź taka zakładałaby zsumowanie całego systemu psychologii i metafizyki - a uczynienie tego nie jest tutaj możliwe. Spróbujemy jednak w kilku słowach zarysować samo sedno problemu.

Jeżeli pytam konkretnie i z naleganiem tego, który czyta moje słowa: Kim Pan jest? - Kim jest ten, którego Pan nazywa ,ja”, a który ma swoje imię i nazwisko? - najbliższa odpowiedź brzmiałaby: „Ja” jestem moim ciałem i duszą, psyche, świadomością lub jak tam zwykło się to nazywać. Ale ja z kolei zwróciłbym uwagę, że pańskie ciało i dusza są rzeczami zastanymi przez Pana w momencie, gdy odkrył Pan siebie jako tego, który żyje. Zastał Pan ciało silne lub słabe, sprawne lub ułomne. Zastał Pan tego, który nie ma 
dobrej pamięci do słów, ale ma za to dobrą pamięć do dat, tego, dla którego proste wydaje się rozumowanie matematyczne, ale który nie może polegać na swojej „silnej woli”. To pokazuje, że ciało i dusza są środkami - lepszymi lub gorszymi - z którymi ten, zwany przez nas ,ja”, zetknął się po to, aby żyć, środkami, które są dla jego życia najbardziej bezpośrednie i ważne, są najbardziej ,,jego", ale w istocie są tyko środkami takimi samymi jak ubiór, majątek, ziemia, którą zamieszkuje, społeczeństwo, w którym się porusza. Jego ciało, dusza, majątek, ziemia, naród są rzeczami w jakimś sensie ,jego”, ale właśnie dlatego nie są nim. Kim jest zatem ów „on”? Jest on tym, który musi z tymi wszystkimi rzeczami żyć. Powiedzieć, że jesteśmy materią lub duchem, to tak, jakby opowiadać bajkę lub w najlepszym wypadku stawiać wiarygodną hipotezę, ale nic ponadto. Trzeba wyzwolić się z tradycyjnej idei, która każe nam wierzyć, że nasza rzeczywistość zawiera się w jakiejś „,rzeczy” czy to cielesnej, czy też myślnej. „Ja”, o którym mówi czytelnik w każdej ze swoich fraz, nie jest ani materią, ani duchem. Jest czymś pierwotniejszym od tych wszystkich „teoretycznych” odpowiedzi. Jest po prostu tym, który musi przeżyć swoje życie. Zauważcie: „swoje życie”, nie „jakiekolwiek życie”, ale życie ściśle określone. Dlatego na przykład dla czytelnika, zdolnego pokochać tylko jedną kobietę, taką, która posiada pewne określone cechy, byłoby zupełnie bezużyteczne, gdyby jego otoczenie przedstawiło mu jakieś inne typy kobiet, nawet wówczas gdyby miał on najlepszą wolę zakochania się. Jeśli ta konkretna kobieta nie pojawi się w jego horyzoncie, czytelnik ten poniesie klęskę na jednym z fundamentalnych poziomów witalnych. Podobnie dzieje się, jeśli czytelnik musi być „światowcem”, ale urodził się w skromnej rodzinie, pozbawionej środków, nie miał szczęścia $w$ interesach i dodatkowo jest bardzo niezgrabny. Taki czytelnik nie mógłby wówczas żyć własnym życiem. Jego ,ja”, to kim on jest, nie mogłoby się zrealizować, ale nie powoduje to wcale, że może on przestać być tym, kim jest, albowiem nadal musi być „światowcem”. Jesteśmy nieusuwalnie tym, kim jesteśmy, i możemy być tylko tym, kim jesteśmy. Jeżeli świat wokół nas - włączając w to nasze ciało i duszę - nie pozwala nam zrealizować naszej egzystencji, tym gorzej dla nas. Ale za próżne należy uznać wszelkie próby modyfikowania tego, kim jesteśmy. Gdyby nasze ,ja” zamiast być autentycznym, byłoby tylko czymś „naszym” — tak jak strój, ciało, talent, pamięć, wola - moglibyśmy spróbować je poprawić, zmienić, pominąć lub zastąpić. Ale ono już tutaj jest, jest naszym własnym bytem, jest tym, czym być musimy, czy tego chcemy, czy też nie. Powie ktoś, że nasze życie nabywa w ten sposób swoistego tragizmu, ponieważ nie 
możemy być tym, kim nieubłaganie jesteśmy. I rzeczywiście tak właśnie jest. Życie to w swojej istocie dramat, albowiem stanowi ono szaleńczą walkę, aby uczynić faktem to, co jest projektem.

Dlatego ,ja" czytelnika jest projektem jego życia. Ale nie chodzi tutaj o jakiś wymyślony przez niego i dowolnie wybrany projekt. Ten ostatni znajduje on już uformowany w momencie, gdy odnajduje siebie jako tego, który żyje. Starożytni mylnie używali terminu, którego prawdziwe znaczenie zbiega się z tym, co nazywam witalnym projektem. Mówili o przeznaczeniu i wierzyli, że chodzi w nim o to, co przydarza się człowiekowi. Bardzo szybko możemy jednak zauważyć, że ta sama rzecz może się przydarzyć dwojgu ludzi, a jednak mieć dla każdego z nich zupełnie inną, a nawet przeciwną wartość. Dla jednego będzie rozkoszą, dla drugiego katastrofą. To, co nam się przydarza, co do wywołanych skutków witalnych zależy zatem od tego, kim jest każdy z nas. Nasz źródłowy byt, egzystencjalny projekt, którym jesteśmy, określa i nadaje wartość temu, co nas otacza. Stąd okazuje się, że prawdziwe przeznaczenie polega na byciu sobą. To, co się nam przydarza, to bycie tym, kim jesteśmy.

Jesteśmy naszym przeznaczeniem, jesteśmy niepodlegającym zmianom projektem pewnej określonej egzystencji. W każdym momencie życia widzimy, czy jej rzeczywistość zbiega się, czy też nie z naszym własnym projektem, i wszystko, co robimy, robimy po to, aby go zrealizować. Albowiem tak jak ów projekt, którym jesteśmy, nie jest wolnym tworem naszej fantazji, tak jego spełnienie lub niespełnienie nie ma nic wspólnego z naszymi pragnieniami. Nic z tych rzeczy! Projekt sam z siebie rzutuje na nasze życie, naciska na nie, wymuszając swoje wykonanie. Dlatego właśnie powiedziałem wcześniej, że czytelnik jest tym, który musi przeżyć pewne określone życie.

Życie jednak jest nie tylko naszym ,ja”, lecz także i światem, w którym owo ,ja” musi się zrealizować. Projekt stanowi swoisty program działania $\mathrm{w}$ świecie i zderza się z tym, czym ten świat jest. Zawsze napotka w nim na większe lub mniejsze trudności. I tu pojawia się inny poziom naszego ,ja”. Zaakceptujemy ten projekt mimo trudności, które staną nam na drodze w jego realizacji? Czy też przeciwnie: zdecydujemy się w takim czy w innym przypadku zdradzić to, kim być musimy, nie godząc się znosić przeciwności, które to „bycie sobą” ze sobą niesie? Skoro jesteśmy witalnym projektem, to nieodzownie decydujemy o jego akceptacji. Ta decyzja ma charakter uprzedni wobec wszelkiego aktu woli. Są osoby, które jednoznacznie akceptują swoje przeznaczenie, swój byt, ale mają bardzo mało silnej woli w jego realizacji. Przykładowo: decyduję się rzucić palenie, ponieważ szkodzi ono mojemu 
zdrowiu i przeszkadza mi w pracy, która jest moim przeznaczeniem. Moja decyzja jest pełna i autentyczna. Nadal jednak palę, gdyż mam słabą wolę. Nasz język wyraźnie odróżnia człowieka „zdecydowanego” od tego, który ma silną wolę. „Zdecydowany” to ten, który natychmiast i w sposób pełny lokuje się w swoim przeznaczeniu, akceptując, że jest ono od zawsze i na zawsze w niego wpisane. Oddaje się więc całkowicie do dyspozycji temu, kim być musi.

Wyobraźcie sobie teraz Państwo odmienny typ człowieka. Taki, który już przy pierwszym zderzeniu swojego ,ja” ze światem czuje, że nie będzie zdolny pozostać sobie wiernym i zachować się w każdej witalnej sytuacji zgodnie z tym, co nakazuje mu jego wewnętrzny projekt. Nie ma on zamiaru cierpieć z powodu swojego przeznaczenia i decyduje się je odrzucić. Czasami jest to człowiek zdolny cierpieć katusze, aby zaspokoić apetyty swojego ciała czy też duszy — na przykład żądzy lub ambicji — ale jest on zarazem niezdolny do tej znacznie bardziej źródłowej formy cierpienia, jaką jest cierpienie $\mathrm{z}$ powodu własnego przeznaczenia. Jako że życie jest zawsze dramatem, będzie nim również życie tego konkretnego człowieka, albowiem ten, który świadomie rezygnuje z bycia sobą, umiera już za życia, popełnia samobójstwo. Jego egzystencja będzie polegać na wiecznej ucieczce od jedynej autentycznej rzeczywistości, jaką mógłby być. Niczego nie będzie czynił powodowany bezpośrednio przez swój witalny program, lecz przeciwnie będzie kompensować sobie aktami taktycznymi, mechanicznymi i pustymi brak autentycznego przeznaczenia.

Wszelkie zło pochodzi z następującego źródła: niedopasowania się do własnego przeznaczenia. Dlatego nie istnieje twórcze zło. Wszelki akt perwersji jest zjawiskiem kompensacji, jakiej poszukuje byt niezdolny dokonać spontanicznego i autentycznego aktu, wyrastającego z jego własnego przeznaczenia. Popularne przysłowie mówi: „Jedno kłamstwo rodzi sto kolejnych". Kłamstwo jest charakterystycznym przykładem działania, w którym człowiek opuszcza swój prawdziwy byt. Prawda mówienia zakłada prawdę myślenia. Nie ma jednak prawdy myślenia, jeśli nie ma prawdy pierwotniejszej — prawdy bytu, prawdy bycia tym, kim się autentycznie jest. I ten, kto kłamie odnośnie do własnego bytu, może egzystować tylko w świecie pozorowanym, w świecie fałszywym. Nietzsche i Scheler badali resentyment jako jedno z tych zjawisk, które nazywam zjawiskami kompensacyjnymi. Ale ich form jest nieskończenie wiele. Teraz zajmiemy się „partyjnością” jako kolejnym przypadkiem kompensacji. 


\section{PARTYJNOŚĆ A IDEOLOGIA}

Już niejednokrotnie miałem okazję zobaczyć, że ignorancja względem historii, prezentowana przez dzisiejszego wykształconego człowieka, jest jednym z największych nieszczęść, jakie niepokoją nasze czasy. Istnieje nieskończona wręcz liczba przykładów, zmuszających mnie do tego, abym tak właśnie myślał. Między nimi znajduje się ten, który obecnie najbardziej nas interesuje. Otóż życie zawsze ma jakąś bezpośrednią przeszłość, taką, którą odnajduje w sobie przy użyciu wspomnień i która nie wymaga odwoływania się do historii. Podobnie my dzisiaj znajdujemy w sobie bazę, z której wyłania się nasze życie, a mianowicie słynny wiek XIX. Ta bezpośrednia przeszłość, jedyna, do jakiej mamy dostęp bez specjalnego wysiłku z naszej strony, będzie w sposób naturalny dążyć do tego, aby oznaczać dla nas całą przeszłość. To, co w niej było i w niej się wydarzyło, zdawać się będzie czymś, co było i wydarzało się zawsze. Jest to jednak tylko nieszczęsny błąd optyczny, albowiem nie ma takiego stulecia, które mogłoby pretendować do bycia adekwatnym przedstawieniem wszystkich pozostałych. W naszym jednak wypadku ta iluzja okazuje się szczególnie fatalna. Niektóre stulecia są bowiem normalniejsze od innych lub - mówiąc inaczej — niektóre są mniej anormalne. Wiek XIX był w najwyższym stopniu anormalny i krytyczny dla ludzkiego przeznaczenia, zarówno gdy mowa o jego wielkości, jak i o przekleństwie. Z niego wyrasta znaczna część naszych obsesji i nasz brak umiaru. Stąd też musimy wyleczyć ten błąd optyczny, zwracając się z prośbą do historii, aby ta wyzwoliła nas z fałszywej normalności, jaką ów wiek ukazuje naszym oczom.

Staje się to szczególnie wyraźne w przypadku „partyjności”. Nie jest prawdą, że istnienie partii jako takich było czymś wśród ludzi normalnym. W mniejszym lub większym stopniu zawsze istniały rywalizujące ze sobą grupy, ale nie oznacza to wcale, że były to „partie”. Jakaś jednostka wyraża i proklamuje uśpione $w$ wielu innych jednostkach pragnienie, te zaś gromadzą się wokół niej i rozpoczyna się walka z całą resztą społeczeństwa w celu jego zaspokojenia. Walka ta prowadzi albo do zwycięstwa, albo do porażki. Jedno i drugie ma identyczny skutek: rozwiązuje się walcząca grupa, a wraz z nią grupa jej przeciwna. Ich rozwiązanie powoduje, że znika także sama walka, a społeczeństwo powraca do pokojowego i jednolitego współżycia. Nikomu nie przychodzi do głowy, aby po wygranej bądź przegranej walce zachować wrogie grupy lub też sam nastrój wrogości. 
Istnienie ,partii” we współczesnym tego słowa znaczeniu zakłada zupełnie odmienną wykładnię życia społecznego od tamtych efemerycznych, walczących ze sobą grup. Jeśli w tych ostatnich substancją było szczerze odczuwane pragnienie, aby osiagnąć taką lub inną korzyść, i tylko dlatego ludzie się grupowali i walczyli, to w „partiach” substancją jest sama „partia”. Pragnie się, aby społeczeństwo było naturalnie podzielone na grupy, bez względu na to, czy istnieją, czy też nie istnieją ku temu powody. Jeżeli takiego powodu nie ma, to trzeba go znaleźć. Należy karmić partię, ożywiając jej wojowniczy program. Uznaje się, że walka stanowi istotę współżycia między ludźmi.

Jakiekolwiek byłyby początki i źródła takiego sposobu myślenia ${ }^{1}$, to pewne wydaje się, że do XIX wieku nie wyłoniła się idea mówiąca, że historia konstytuuje się przez wieczystą walkę. Być może Guizot jest pierwszym myślicielem, który otwarcie mówi o walce klas jako źródłowym napędzie dziejowego procesu ${ }^{2}$. Aż do tamtego momentu idea ta wydawała się anormalnością tak częstą, jak przykrą, ale zawsze czymś tylko przypadkowym, choć w jakimś stopniu też charakterystycznym dla ludzkiego współżycia. Permanentna rywalizacja miała miejsce tylko między oderwanymi społecznościami - miastami, narodami, państwami - i była przez to symptomem braku stabilności. Dla starożytnego Greka i Rzymianina społeczeństwo przedstawia się pod postacią miasta, a miasto pod postacią municypium dawnych wrogów, ich przymierza, które zawiązuje się po to, aby mogli oni żyć razem w pokoju i w jedności (synoikismós). Stąd też prototypem anormalności społecznej była dla nich wojna domowa.

Bez wątpienia wewnętrzna walka jest bardzo częstym faktem na przestrzeni ludzkiej historii. Dlatego też zaskakuje odmienność reakcji, jakie wobec niej przyjmują różne epoki. Te wcześniejsze interpretowały ją jako nieszczęście, a w rezultacie jako anomalię i coś przypadkowego. Wiek XIX, przeciwnie, szczycił się tym, że nie robił sobie złudzeń, że brał rzeczywistość taką, jaką ona była. Ale to doprowadziło go najpierw do uciążliwego pesymizmu. Z przypadkowego nieszczęścia uczyni on samą substancję. Społeczeństwo stanie się w istocie walką i niczym więcej. Współżyć oznacza

\footnotetext{
${ }^{1}$ Na przykład u Juana Bautisty Vico.

${ }^{2}$ François Guizot (1787-1874) — francuski polityk, historyk i mąż stanu. Uważany jest za twórcę terminu „walka klas”, który został następie przejęty i rozpowszechniony przez Marksa i Engelsa za sprawą ogłoszonego przez nich w Londynie w 1848 r. Manifestu partii komunistycznej. Zob. Karol Marks i Fryderyk Engels, Manifest komunistyczny, przeł. Tadeusz Zabłudowski, w: Karol Marks, Fryderyk Engels, Dzieła, t. 4 (Warszawa: Książka i Wiedza, 1962), 511-549. (Przyp. tłum.).
} 
walczyć - szczerze lub pozornie. Podobnie ówcześni psychologowie, którzy usiłowali nas przekonać, że percepcja świata zewnętrznego to wspólnotowa halucynacja. Z faktu, że często błądzimy, wysnuli oni wniosek, że prawda jest powszechnym błędem.

Temu pesymizmowi w koncepcji rzeczywistości towarzyszył cynizm w moralności. Jako że społeczeństwo stanowi istotową walkę - mówiono - poświęćmy się wszyscy świadomie walce. Zanegujmy prawo do robienia czegoś innego. A skoro walka wymaga wojujących grup, uczyńmy z nich substancjalną formę ludzkiej egzystencji. Najważniejsza na świecie stanie się partia, organizacja ponadindywidualna, stworzona po to, aby walczyć. Jednostki się nie liczą, ponieważ umierają, i należy zapewnić przetrwanie partiom. Każdy człowiek będzie członkiem jakiejś partii, a jego idee i uczucia będą partyjne. Nie ma czegoś takiego, co byłoby zgodne z prawdą, ze zdrowym rozsądkiem, z tym, co słuszne i właściwe. Prawda i sprawiedliwość nie istnieją. Jest tylko to, co odpowiada partii, i to stanowić będzie prawdę oraz sprawiedliwość. Rozumie się przy tym, że będzie tyle prawd i tyle sprawiedliwości, ile będzie partii.

Marksizm stanowi uteoretycznienie tej cynicznej partyjności. Jak każdy cynizm przekształca on wadę, na którą sam cierpi, w zaletę. Operacja ta nie została arbitralnie przeprowadzona przez Marksa. Cały pochód idei od XVIII stulecia przygotował możliwości, które Marks doskonale wykorzystał. Racjonalizm tamtego wieku nie spłodził innej prawdy niż ta schematyczna, pozbawiona ewolucji i zmiany. Dlatego nie potrafił wyjaśnić, jak to jest możliwe, że w dziejach istniały odmienne od niego sposoby myślenia. Starożytne religie, formy prawne etc. rozumiano tylko jako oszustwo, celowe zafałszowanie, którego cel inspirował niektórych ludzi. Idea, że myślenie inne niż nasze jest fałszerstwem, inicjuje walki polityczne we współczesnej epoce. Napoleon ukuł specjalne słowo, aby określić to fałszywe myślenie, nazywając swoich wrogów pogardliwie ,ideologami”. Od tamtej pory ideologia znaczyła zbiór wymyślonych przez jakąś grupę idei, aby ukryć pod nim swoje interesy, maskując je szlachetnymi wyobrażeniami i rzekomymi argumentami. Filozofia romantyczna przejęła ten termin i uwolniła go od tego pejoratywnego znaczenia. Pokazała, jak rozum, nie tracąc swojej ostatecznej jedności, żyje ewolucyjnie, przyjmuje odmienne oblicza w różnych epokach i narodach, usprawiedliwiła różnorodność opinii. Każdy „duch narodu” — Volksgeist —

\footnotetext{
${ }^{3}$ Ortega ma tutaj na myśli tzw. szkołę ideologów, utworzoną na bazie filozofii encyklopedystów przez hrabiego Antoine'a Destutt de Tracy na początku XIX stulecia. Szkoła ta występowała otwarcie przeciwko polityce Napoleona, co doprowadziło ostatecznie do jej upadku. (Przyp. tłum.).
} 
ma własną, nieuniknioną, niezbywalną ideologię. Wówczas właśnie zabiera głos Marks i funduje oba znaczenie terminu ,ideologia”, zarówno to pejoratywne, jak i pozytywne. Historia jest walką, a szczególnie walką klas ekonomicznych. Każda klasa myśli o świecie powodowana swoimi interesami. Gdy walczy o przewagę, jej interes staje się prawdą, ale kiedy zwycięża, przechodzi do defensywy, a jej idee odzwierciedlają jedynie status quo ekonomicznej infrastruktury. W jednym i w drugim przypadku człowiek nie jest wolny w swoich opiniach na temat rzeczywistości. Wcześniej było inaczej. Odtąd zaś opinie człowieka zależały od tego, jaka była jego rzeczywistość społeczna. Istnieje „prawda burżuazyjna”, która oczywiście nie jest prawdą, a jedynie ideologią burżuazyjnej klasy. Ideologia oznacza więc zafałszowanie prawdy przez człowieka, ale nie w sposób celowy (nie jest ona oszustwem), lecz nieuchronny, wskutek przypisania go do takiej lub innej klasy. Formuła Marksa jest następująca: „Nie sposób myślenia ludzi określa ich rzeczywistość, lecz rzeczywistość społeczna określa ich sposób myślenia" (Krytyka ekonomii politycznej) ${ }^{4}$. Każda opinia powstaje w zależności od społecznego miejsca, z jakiego została pomyślana — z góry lub z dołu, bądź też, co oznacza to samo, każda idea jest partyjna. W rezultacie stajemy się bardziej partyjni, niż być możemy ${ }^{5}$.

Jak widać, myśl Marksa jest w tym punkcie jednym z niezliczonych pędów XIX-wiecznego relatywizmu i niesie z sobą wszystkie związane z nim problemy. Odkrycie ideologii klas staje się kluczowe, ale tylko wówczas, gdy sprowadzi się je do pojęć, w ramach których uzyskuje ono swoje faktyczne znaczenie, to znaczy: jeśli w ideologii klas widzi się jedynie fakt empiryczny. Jest to częsta tendencja u wielu ludzi, że pozwalają, aby ich interesy wpływały na głoszone przez nich idee. Marks jednak nadał absolutny i metafizyczny charakter pojęciu walki klas, co jest bez wątpienia absurdalne i fał-

\footnotetext{
${ }^{4}$ Fragment ten brzmi u Marksa następująco: „W społecznym wytwarzaniu swego życia ludzie wchodzą w określone, konieczne, niezależne od ich woli stosunki, w stosunki produkcji, które odpowiadają określonemu szczeblowi rozwoju ich materialnych sił wytwórczych. Całokształt tych stosunków produkcji stanowi ekonomiczną strukturę społeczeństwa, realną podstawę, na której wznosi się nadbudowa prawna i polityczna i której odpowiadają określone formy świadomości społecznej. Sposób produkcji życia materialnego warunkuje społeczny, polityczny i duchowy proces życia w ogóle. Nie świadomość ludzi określa ich byt, lecz przeciwnie, ich byt społeczny określa ich świadomość". Karol MARKs, Przyczynek do krytyki ekonomii politycznej, przeł. Edward Lipiński (Warszawa: Książka i Wiedza, 1951), 5-6. Zacytowany w tekście fragment thumaczymy zgodnie z literą eseju Ortegi. (Przyp. tłum.).

${ }^{5}$ Zob. Karl Mannheim, Ideologie und Utopie (Bonn: Cohen, 1929). Polski przekład: Ideologia i utopia, przeł. Jan Miziński, wstęp do wyd. polskiego Jadwiga Mizińska, wyd. I, Lublin: Wydawnictwo Test, 1992; wyd. II: Warszawa: Wydawnictwo Fundacji Aletheia, 2008.
} 
szywe. Marks nie może dowieść ani tego, że każda jednostka wpisuje się w temperament swojej klasy, ani też, że myślenie jednostki w sposób nieuchronny warunkowane jest przez klasę. Co prawda zdarza się czasem takie uwarunkowanie, ale ostatecznie jest ono niczym innym, jak życiem ludzi, którzy walczą o wyzwolenie własnej ideacji ze swojego stanu ekonomicznego i czasami udaje im się to osiagnąć. Przykładem jest Karol Marks. Znaczna porcja prawdy, jaką można znaleźć w materializmie historycznym, pozwoliła zerwać wiele masek i obnażyć wiele ,idealistycznych" twarzy. Ale on sam, przyznając się do tego czy też nie, aspiruje do bycia jedyną prawdą. Przez nieuniknioną jednak konieczność sam rdzeń ludzkiego bytu dąży do tego, aby nie być partyjnym i kiedy zostaje sam na sam ze sobą, brzydzi się swojej partyjności.

\section{Z języka hiszpańskiego przełożyła Dorota Leszczyna}

\section{BIBLIOGRAFIA}

Marks, Karol, i Fryderyk Engels. Manifest komunistyczny. Przełożył Tadeusz Zabłudowski. W: Karol MARKS i Fryderyk Engels. Dzieła. T. 4, 511-549. Warszawa: Książka i Wiedza, 1962.

MARKS, Karol. Przyczynek do krytyki ekonomii politycznej. Przełożył Edward Lipiński. Warszawa: Książka i Wiedza, 1951

MannheIM, Karl. Ideologie und Utopie. Bonn: Cohen, 1929. Polski przekład: Ideologia i utopia. Przełożył Jan Miziński, wstęp do wyd. polskiego Jadwiga Mizińska. Wyd. I. Lublin: Wydawnictwo Test, 1992; Wyd. II: Warszawa: Wydawnictwo Fundacji Aletheia, 2008.

\section{NIE BYĆ CZŁOWIEKIEM PARTYJNYM}

Streszczenie

Esej „No ser hombre de partido” autorstwa José Ortegi y Gasseta ukazał się po raz pierwszy w argentyńskim czasopiśmie La Nación. Został podzielony na dwie części. Pierwszą opublikowano 15 maja 1930 r., drugą zaś 3 czerwca 1930 r. Przedmiotem refleksji jest tutaj problem „partyjności”, który rozpatruje się z dwóch perspektyw — metafizycznej i społecznej. Pierwsza czyni z ,partyjności” przejaw kompensacji, tj. zafałszowania własnego bytu i braku akceptacji

Dr hab. Dorota LeszCzyna — doktorat z filozofii uzyskała na Wydziale Nauk Społecznych Uniwersytetu Wrocławskiego, habilitację natomiast na Wydziale Humanistycznym Uniwersytetu Mikołaja Kopernika w Toruniu. Doktorat z nauk politycznych został jej przyznany przez Radę Wydziału Prawa Uniwersytetu w Alicante, Hiszpania. Od 2011 r. adiunkt w Zakładzie Filozofii Nowożytnej w Instytucie Filozofii na Wydziale Nauk Społecznych Uniwersytetu Wrocławskiego; adres do korespondencji — e-mail: d.leszczyna@wp.pl; ORCID: https://orcid.org/0000-00015172-0911. 
dla własnego powołania. Druga z kolei wskazuje, że partyjność stanowi zjawisko historyczne, którego początki sięgają XIX stulecia. To wówczas pojawia się po raz pierwszy wykładnia społeczeństwa jako permanentnej i wiecznej walki, co wymaga ukonstytuowania walczących ze sobą grup, tj. partii. Ortega natomiast pragnie przezwyciężyć obie wersje partyjności. Dlatego staje po stronie autentyczności naszego jednostkowego życia i nieuwarunkowanych partyjnie idei, uczuć i wartości.

\section{NOT TO BE A PARTY MAN}

\section{S u m m a r y}

The essay „No ser hombre de partido” by José Ortega y Gasset was published for the first time in the Argentinian magazine La Nación. It has been divided into two parts. The first was published on May 15, 1930. The second was June 3, 1930. The subject of reflection is the problem of "partisanism," which is considered from two perspectives - metaphysical and social. The first one makes "partisanism" a manifestation of compensation, falsification of one's being and lack of acceptance for one's own vocation. The second one indicates that "partisanism" is a historical phenomenon, the beginning of which is the nineteenth century. Then, for the first time, society is understood as a permanent and eternal struggle. This requires as a consequence the constitution of fighting groups, called parties. Ortega, on the other hand, wants to overcome both versions of "partisanism." Therefore, it is on the side of the authenticity of our individual life and independent of the party, ideas, feelings and values.

Słowa kluczowe: partyjność; autentyczność; ideologia; walka klas; Karol Marks; materializm historyczny.

Key words: partianism; authenticity; ideology; class conflict; Karl Marx; historical materialism.

Information about Author: José ORTEGA y GASSET (1883-1955) - Spanish philosopher, essayist, social activist. Initially, he was influenced by neo-Kantianism and phenomenology. Then he created his own philosophical concept known as "racio-vitalism" or the "philosophy of vital reason." His most important woks are: Meditaciones del Quijote (1914), El tema de nuestro tiempo (1923) and La rebelión de las masas (1930).

Information about Translator: Dr hab. Dorota LESZCZYNA - PhD with habilitation in Philosophy awarded by the Council of the Faculty of the Human Sciences at the Nicolaus Copernicus University in Torun, and $\mathrm{PhD}$ in Political Sciences awarded by the Council of the Faculty of Law, University of Alicante, Spain. Since 2011 assistant professor at the Department of Modern Philosophy, Institute of Philosophy, Faculty of Social Sciences, University of Wrocław; address for correspondence — e-mail: d.leszczyna@wp.pl; ORCID: https://orcid.org/0000-0001-51720911. 
